\title{
Kemiskinan dalam Perspektif Sosiologi
}

\author{
Sulistya Wardaya, ${ }^{1}$ Anni Suprapti ${ }^{2}$ \\ ${ }^{1}$ Fakultas Ilmu Sosial dan Ilmu Politik Universitas Bengkulu \\ 2Fakultas Keguruan dan Ilmu Pendidikan Universitas Bengkulu \\ (e-mail: ${ }^{1}$ wardoyo@yahoo.com; ${ }^{2}$ annisuprapti@yahoo.com)
}

\begin{abstract}
This paper describes the social and cultural situation of Pematang Gubernur Village, Muara Bangka Hulu Sub-district, Bengkulu City. Formerly, this area belongs to Suku Lembak who lived in Tanjung Agung and Tanjung Jaya village. The population of Pematang Gubernur has increased along with the establishment of Bengkulu University housing and the relocation of government office of Bengkulu City to Muara Bangka Hulu Sub-district. Based on the sociological analysis, Suku Lembak becomes a minority group in their own territory and as a minority, they are no longer able to carry out their customs and traditions, in contrast, the migrants that have become majority group, in fact, can apply their traditions and rituals from their origin. This research found that the social structure of Pematang Gubernur Village is seeking its ideal format. The community of the village is diverse and live in different groups based on housing complex and kampong. This makes the community divided and trapped in the situation in which the interaction between groups is limited. This also makes the community of Padang Gubernur has a narrow perspective in understanding poverty by seeing it as merely a problem of success and failure in pursuing the career and business of their neighbors. They also have narrow self-orientation and non-competitive capacities.
\end{abstract}

Artikel ini secara sosiologis mendeskripsikan kondisi sosial budaya Kelurahan Pematang Gubernur, Kecamatan Muara Bangka Hulu, Kota Bengkulu. Karakter daerah ini menarik diteliti karena dulunya merupakan kebun milik Suku Lembak yang tinggal di desa Tanjung Agung dan Tanjung Jaya, Kota Bengkulu. Jumlah warganya kian meningkat seiring berdirinya perumahan Universitas Bengkulu, dan perpindahan pusat perkantoran Kota Bengkulu ke kecamatan Muara Bangka Hulu. Berdasarkan analisis sosiologis, masyarakat Suku Lembak menjadi minoritas di wilayahnya sendiri, hukum adat tidak berlaku. Warga pendatang menjalankan ritual adat daerah asalnya. Hasil penelitian menunjukkan bahwa struktur sosial masyarakat Kelurahan Pematang Gubernur masih mencari bentuk yang ideal, Masyarakatnya sangat heterogen dan menetap secara berkelompok dalam bentuk perumahan dan perkampungan. Masyarakat menjadi terbelah, terkotak-kotak, dan terperangkap dalam wilayah interaksi yang terbatas. Situasi ini membuat mereka berpikir sempit dalam memaknai arti kemiskinan. Mereka mengukur kemiskinan berdasarkan keberhasilan dan kegagalan dalam karir dan usaha tetangganya. Mereka memiliki orientasi diri sempit, sehingga kurang kompetitif dari kemampuan yang dimilikinya.

Keywords: Kelurahan Pematang Gubernur; ukuran kemiskinan 


\section{Pendahuluan}

Kajian sosiologis terhadap kemiskinan berhubungan dengan tingginya tingkat pertumbuhan penduduk dan rendahnya ketersediaan lapangan pekerjaan. Masyarakat desa yang berada dalam usia produktif, lebih memilih mengadu nasib dengan pergi ke kotakota untuk mendapatkan pekerjaan daripada menjalani rutinitas monoton di kampung halamannya. Para pendatang ini tentu bukan dengan begitu saja terbebas dari masalah. Mereka menghadapi masalah baru di tempat tujuan yakni persoalan pemukiman, perumahan, kediaman yang layak dan pantas. Pada titik ini tanah dan perumahan di lingkungan yang baru memiliki arti penting bagi para pendatang. Urbanisasi sebagai salah satu akibat dari ledakan penduduk, akhirnya berdampak terhadap mobilisasi masyarakat dari desa ke kota. Persaingan dalam mendapatkan pekerjaan juga kian meningkat dan menimbulkan gesekan-gesekan baru antar sesama warga pendatang dan pendududuk asli (Adams 1993).

Pemerintah Indonesia melalui amanat Pembukaan UUD Negara Republik Indonesia tahun 1945 memiliki komitmen mensejahterakan rakyatnya. Seluruh rakyat Indonesia, tanpa terkecuali, berhak untuk mendapatkan kehidupan yang layak. Pasal 34 ayat (1) Undang-Undang Dasar 1945 menyebutkan bahwa "Fakir miskin dan anak-anak terlantar dipelihara oleh negara". Maka pemerintah selaku pengemban mandat negara berupaya untuk merealisasikan kebijakan pengentasan kemiskinan yang dilaksanakan secara serentak.
Badan Pusat Statistik (BPS) memberikan ukuran kemiskinan berdasarkan pengeluaran kebutuhan minimum dan makanan yang disetarakan dengan 2100 kilo kalori perkapita perhari. Takaran ini bisa bisa disetarakan juga dengan paket komoditi kebutuhan dasar dari 52 jenis komoditi (padi-padian, umbi-umbian, ikan, daging, telur dan susu, sayuran, kacangkacangan, buah-buahan, minyak dan lemak, dan lain-lain). Maka dari itu, jika penduduk yang memiliki rata-rata pengeluaran perkapita perbulan di bawah garis kemiskinan, dikategorikan sebagai penduduk miskin (Cahyat 2004).

Berdasarkan data BPS, dinas instansi pemerintah melaksanakan berbagai program, antara lain Inpres Kesehatan, Inpres Perhubungan, Inpres Pasar, Bangdes, Inpres Desa Tertinggal. Program-program pemberdayaan lainnya dapat dilihat dalam bentuk Program Pembinaan dan Peningkatan Pendapatan Petani dan Nelayan Kecil(P4K), Program Tabungan dan Kredit Usaha Kesejahteraan Rakyat (Takesra-Kukesra), Program Pengembangan Kecamatan (PPK), Program Penanggulangan Kemiskinan Perkotaan (P2KP), Program Pembangunan Prasarana Pendukung Desa Tertinggal (P3DT), dan lain sebagainya. Akan tetapi sebagian besar hasilnya belum bisa memuaskan. Berdasarkan data Badan Pusat Statistik (BPS) tanggal 18 Juli 2016 jumlah penduduk miskin dengan pengeluaran per kapita perbulan di bawah garis kemiskinan mencapai 28,01 juta jiwa atau sebesar 10,86 persen dari total jumlah penduduk Indonesia. Ternyata di kalangan para ilmuwan ukuran 
kemiskinan masih diragukan kebenarannya, mengingat keragaman kultur bangsa Indonesia memiliki ragam nilai yang berbeda-beda (Kleden dan Humaedi 2010).

Tulisan ini menggunakan pendekatan deskriptif dengan tujuan untuk mengungkap gejala sosial yang lebih rinci, terstruktur, sistematis dan terkontrol. Pada pelaksanaannya penulis dapat mengungkap secara ilmiah kondisi obyek yang ditulis, sedangkan posisi peneliti sebagai instrumen kunci. Teknik pengumpulan data dilakukan secara triangulasi (gabungan), dan analisa data bersifat induktif/kualitatif (Bungin 2007). Hasil penelitian lebih menekankan makna dari pada generalisasi, dan diharapkan dapat mengungkapkan fenomena sosial yang belum diketahui atau tidak bisa dibaca dan dikenali melalui sederet angka atau statistik (Moleong 2002). Maka untuk lebih menyempurnakan pemahaman tentang permasalahan yang dikaji, berikut disampaikan konseptualisasi dan operasional penelitian pada Tabel 1 .

Beberapa tulisan hasil penelitian lain telah menjadikan kemiskinan sebagai tema besar yang menjadi fokusnya. Seperti sebuah buku lawas kumpulan tulisan dengan judul, Perangkap Kemiskinan, (Suyanto, ed. 1995). Kemudian kumpulan tulisan dengan judul, Kemiskian di Perkotaan,(Suparlan, ed. 1993). Selain itu artikel dari sejumlah jurnal juga telah menampilkan tema kemiskinan seperti tulisan Rusli Cahyadi (2011), tentang "Kaum Miskin Kota, Sampah, dan Rumah: Studi tentang Akses Migran Miskin terhadap Sumber Daya Lingkungan dan Perumahan di Tangerang", yang dipublikasikan dalam jurnal Masyarakat. Kemudian Mochamad Syawie (2011) menulis tentang "Kemiskinan dan Kesenjangan Sosial", dalam Jurnal Informasi.

Tabel 1.

Konseptualisasi dan Operasional Penelitian

\begin{tabular}{llll}
\hline \multicolumn{1}{c}{$\begin{array}{c}\text { Aspek } \\
\text { Penelitian }\end{array}$} & Subyek yang diteliti & Konseptualisasi & Operasional \\
\hline Ukuran & - Penduduk asli Suku Lembak & - Struktur sosial & - Penguasaan lahan \\
Kemiskinan & - Pendatang lokal dari berbagai & - Sistem sosial & - Pemilikan rumah \\
& kabupaten yanga ada di & - Nilai sosial & - Penguasaan barang industri \\
& Bengkulu & & - Pekerjaan/pendapatan \\
& - Pendatang dari luar Propinsi & & - Pangkat jabatan \\
& Bengkulu & & - Prestise/kebanggaan \\
\hline Perspektif & - Cara pandang berdasarkan & - Pola interaksi & - Ruang bergaul/ bersosialisai \\
sosiologi & keilmuan sosiologi & - Mobilitas sosial & - Intensitas perjalanan di luar \\
& & - Orientasi sosial & kota \\
& & - Makna sosial & - Pembanding keberhasilan \\
& & & hidup \\
& & & Ukuran keberhasilan bagi \\
\end{tabular}


Sosiologi sebagai ilmu yang berdiri sendiri menawarkan suatu cara pandang dalam melihat realita sosial. Cara kerja sosiologi sebagai ilmu murni selalu berdasarkan pengamatan di lapangan (empiris), dan secara teoritis selalu berusaha menyusun abstraksi dari hasil observasi, teori-teori yang ada dikembangkan (kumulatif). Sosiologi tidak mempersoalkan baik dan buruk, tetapi menjelaskan fakta secara analistis sebagai bentuk pengembangan ilmu murni (non etnis). Sesuai dengan pendapat Robert Friedrikchs (dalam Ritzer 2009) bahwa pokok persoalan setiap disiplin ilmu memiliki ketetapan yang dapat dijamin kebenarannya sehingga hasilnya dapat diterima secara umum. Selain itu, Durkheim (dalam Ritzer 2009) secara tegas membedakan objek kajian sosiologi dengan objek kajiana disilin ilmu lainnya. Ia mengatakan bahwa fakta sosial sebagai pokok persoalan yang harus dipelajari oleh disiplin sosiologi.

Tetapi sejumlah tulisan di awal tidak menjadikan warga masyarakat Pematang Gubernur sebagai subjek penelitian. Maka dari ini tulisan ini tentunya menjadi berbeda dengan tulisan sebelumnya yang mengulas tema kemiskinan. Tulisan ini menjadikan warga masyarakat Pematang Gubernur Kota Bengkulu yang heterogen dan dinamis sebagai lokusnya. Sehingga tulisan ini tentu menjadi berbeda dengan tulisan terdahulu. Tulisan ini lebih fokus pada bagaimana memahami ukuran kemiskinan pada warga masyarakat pematang gubernur dari perspektif sosiologis. Sejumlah konsep kunci dalam studi sosiologi menjadi kerangka dalam menjelaskannya seperti struktur sosial, nilai sosial, interaksi dan mobilitas sosial. Konsep-konsep sosiologis ini dipakai untuk menemukan makna kemiskiann dalam perspektif sosiologis menurut warga masyarakat Pematang Gubernur.

\section{Dinamika Sosial}

Terbukanya wilayah baru ternyata memiliki cerita tersendiri dimana kehadiran para pendatang selalu mengajak saudara atau kawan, dan hasil survey menunjukkan bahwa banyak responden yang menyatakan awal kehadirannya karena diajak membeli kebun, tanah kaplingan dan perumahan. Secara sosiologis kelompok yang ada sekarang sesungguhnya adalah komunitas yang sudah mapan karena terbukti sudah mampu membeli tanah atau rumah.

Masyarakat Pematang Gubernur secara umum sangat dinamis, selalu ada perubahan dan pertumbuhan, para pendatang rata rata adalah keluarga muda yang mulai berkarir dan berusaha untuk menyongsong masa depan. Kalau dirunut dari awal sampai sekarang tentunya bisa ditemukan orang orang yang bisa dinyatakan berhasil dalam karir dan ekonomi.

Jika menggunakan teori dinamika sosial, untuk mengkaji masyarakat menjadi sangat luas karena menyangkut perubahan sosial yang terjadi. Seperti yang dijelaskan Selo Soemardjan dalam (Soekanto 2013) bahwa perubahan yang terjadipada masyarakat dapat berupa perubahan-perubahan nilai-nilai sosial, norma-norma yang berlaku di masyarakat, pola-pola perilaku individu dan organisasi, susunan lembaga kemasyarakatan, lapisanlapisan maupun kelas-kelas dalam masyarakat, kekuasaan, dan wewenang. 
Fakta lapangan menunjukkan kondisi masyarakat masih dalam proses adaptasi dari perbedaan suku budaya dan agama sehingga bentuk pelapisan sosial masih sangat dinamis. Masyarakat masih tumbuh kembang belum mapan, pangkat dan jabatan selalu silih berganti, kekayaan selalu bergerak seiring dengan perkembangan industri.

\section{Struktur Sosial}

Struktur sosial merupakan suatu gagasan tentang kesatuan kehidupan bersama dalam suatu masyarakat. Gagasan ini adalah abstraksi dari praktik-praktik sosial yang berlangsung antar individu dan kelompok dalam masyarakat. Struktur sosial pada satu sisi memengaruhi praktik bertindak individu, dan di sisi lain ia adalah sekaligus media yang dihasilkan dari praktik tindakan itu sendiri. Pada titik ini struktur sosial menjadi dasar dari pola-pola kehidupan sosial dalam masyarakat, tetapi ia juga terus mengalami perubahan, berdinamika menyesuaikan dengan praktikpraktik sosial oleh individu (Abercrombie, Hill, dan Turner 2010: 525).

Kehadiran para pendatang di Kelurahan Pematang Gubernur dapat terdeteksi mulai tahun 1993 dimana rata-rata mereka adalah pasangan muda yang mulai meniti karir dalam kerja dan usaha. Dalam rentang waktu yang panjang sampai pada tahun 2017 secara nyata terjadi peningkatan status sosial dan ekonomi yang dapat dilihat langsung terutama berubahnya bentuk rumah dan kepemilikan kendaraan yang digunakan. Demikian juga di sektor pendidikan terjadi loncatan yang luar biasa. Sekarang banyak warga Pematang Gubernur yang bergelar profesor, doktor, master dan sarjana, sehingga data tahun 2017 Kelurahan Pematang Gubernur dapat dinyatakan memiliki tingkat pendidikan yang paling tinggi dibandingkan dengan Kelurahan lain di Kota Bengkulu.

Banyaknya anggota masyarakat yang memiliki latar belakang pendidikan tinggi memberi implikasi positif bagi warga secara keseluruhan. Pada pertemua-pertemuan rutin warga, aspirasi warga dapat tersampaikan secara terbuka dan egaliter. Tradisi ini tentu sangat baik untuk kemajuan bersama dan sebagai bentuk proses penanaman nilai-nilai demokratis kepada warga. Banyaknya anggota masyarakat yang berpendidikan tinggi akhirnya membuka ruang bagi sistem demokrasi bisa berjalan dengan baik, terutama memberi hak bicara dalam menentukan keputusan bersama. Para tokoh adat dan unsur pemerintahan sering mendapat masukanmasukan positif dalam memimipin pertemuan, karena banyak warga yang memahami persoalan-peersoalan hukum dan peraturan pemerintah.

Secara historis masyarakat Pematang Gubernur masih relatif baru terbentuk dan dapat dinyatakan belum melampaui generasi pertama, tetapi baru meginjak kegenerasi yang kedua, maka belum tampak jelas produk budaya baru dari hasil asimilasi atau akulturasi, tetapi yang tampak masih budaya bawaan daerah asal. Sedangkan untuk struktur ekonomi bisa terlihat dengan jelas, sesuai dengan perjalanan masa kerja karir dan usaha 
yang dicapai setiap keluarga, hasilnya ada perubahan bangunan rumah, memiliki kendaraan pribadi dan menguasai produk industri yang bisa dijadikan simbol status dalam lingkungnnya.

\section{Lembaga Sosial}

Istilah lembaga (institution) banyak digunakan untuk menggambarkan praktik-praktik sosial yang berulang secara teratur dan terusmenerus, didukung dan dipelihara oleh norma-norma sosial, dan memiliki signifikansi yang besar dalam struktur sosial (Abercrombie et al. 2010: 280). Sejalan dengan berkumpulnya individu dalam kelompok yang membentuk masyarakat tentunya menginginkan kenyamanan, keamanan, dan kebersamaan yang diikat dalam bentuk kesepakat bersama dalam wadah lembaga sosial. Itu semua untuk mengatur tata cara dalam melakukan hubungan antar manusia guna mencapai tujuan bersama yang teratur dan seimbang.

Para sosiolog telah mengidentifikasikan setidaknya ada lima kompleks lembaga, yang meliputi (Abercrombie et al. 2010: 280): 1) Lembaga ekonomi berfungsi untuk memproduksi dan mendistribusikan barang dan jasa. 2) Lembaga politik mengatur penggunaan dan akses terhadap kekuasaan. 3) Lembaga stratifikasi menentukan distribusi posisi dan sumber daya. 4) Lembaga kekerabatan berurusan dengan pernikahan, keluarga, dan sosialisasi kaum muda. 5) Lembaga kebudayaan menaruh perhatian pada aktifitas keagamaan, keilmuan, dan kesenian.
Seluruh masyarakat kelurahan Pematang Gubernur secara administrasi terikat penuh sebagai warga negara yang patuh terhadap pemerintah daerah yang ditata secara langsung oleh Lurah, RW dan RT. Akan tetapi dalam kesehariannya warga kelurahan Pematang Gubernur dikendalikan oleh tata aturan berdasarkan kebiasaan dan kesepakat yang dikemas dalam hukum adat dan agama. Bukti lapangan menunjukkan bahwa interaksi yang berlangsung antar warga dapat dikatakan sangat individual sesuai dengan bidangnya, tetapi untuk kebersamaan sangat diwarnai dengan toleransi dan tenggang rasa yang sangat kuat.

Hasil penelitian menunjukkan bahwa lembaga sosial yang ada dalam masyarakat Pematang Gubernur masih dalam proses penyesuaian untuk mencari bentuk. Fakta lapangan membuktikan bahwa setiap ada masalah antar warga selalu diselesaikan dengan cara kesepakatan bersama.

Lembaga adat secara resmi sudah dibentuk berdasarkan peraturan pemerintah, tetapi dalam masyarakat belum memiliki ketetapan mengikat karena setiap warga masih mengedepankan budaya asal, sedangkan yang berkait dengan masalah lembaga agama bisa dinyatakan sudah mapan dan berjalan dengan baik, karena segala macam aturan sudah ada dan baku, sehingga bagi yang beda agama cukup menyesuaikan diri.

\section{Perspektif Sosial}

Memahami masalah perspektif sosial tentunya menjadi sangat mudah kalau pem- 
bangunan fasilitas sosial dan fasilitas umum berkembang dengan cepat sehingga menjadi daya tarik tersendiri. Semua persyaratan yang ditetapkan untuk menjadi daerah maju sudah tercukupi di Kelurahan Pematang Gubernur.

Kondisi yang nyata ada, segala kebutuhan rumah tangga bisa dapat terpenuhi tanpa harus keluar dari wilayah kelurahan, demikian juga untuk pendidikan anak dari PAUD, SD SMP, SMA dan Perguruan Tinggi semua bisa dijangkau dengan mudah dan cepat.

Posisi Kelurahan Pematang Gubernur sangat menguntungkan kalau dilihat dari jalur transportasi, menuju ke pusat kota yang berjarak hanya $9 \mathrm{~km}$, dan ke pusat Ibu kota Propinsi 12 km. Sedangkan untuk menuju ke seluruh kabupaten yang ada di Propinsi Bengkulu relatif lancar tidak ada hambatan. Situasi yang lebih menguntungkan lagi adalah wilayah kelurahan dilewati jalur penghubung lintas barat Pulau Sumatera, dari Aceh sampai Lampung.

Kondisi geografisnya sangat tepat untuk dijadikan sebaga lokasi pusat hunian, mengingat kontur tanah berbukit-bukit, otomatis seluruh limbah bisa langsung turun mengalir dengan cepat menuju ke laut, maka dapat dijamin tidak akan ada banjir. Dengan kondisi wilayah yang relatif bagus untuk pusat pengembangan, maka sejak tahun 2015 seluruh layanan perkantoran Kota Bengkulu berangsur-angsur dipindahkan ke desa Bentiring yang berlokasi bersebelahan dengan wilayah kelurahan Pematang Gubernur. Perpindahan komplek perkantoran Kota Bengkulu berdampak terhadap meningkatnya geliat perekonomian di Pematang Gubernur. Salah satunya adalah harga kampling tanah melambung tinggi.

\section{Norma dan Nilai}

Norma (norm) adalah harapan bersama tentang perilaku yang pantas yang berfungsi sebagai pedoman umum tiap-tiap individu berinteraksi sosial dalam masyarakat (Abercrombie et al. 2010: 384). Kepatuhan terhadap norma-norma bersama, akan menampilkan perilaku manusia (individu) yang teratur. Sedangkan nilai (value) adalah nilai umum yang bersifat stabil yang dianggap sah dan mengikat kehidupan bersama dan dijadikan standar bertindak (Abercrombie et al. 2010: 260). Norma dan nilai sedikit banyak memiliki pengertian yang mirip dalam pemahaman sosiologis. Norma-norma sosial mengandung nilai-nilai ideal yang dimiliki masyarakat dalam kehidupan bersama. Nila-nilai ideal yang telah disepakati bersama ini, kemudian bersifat mengikat tiap-tiap individu dalam bertidak, sehingga menjadi norma umum dalam kehidupan bersama.

Kaidah norma yang ada di masyarakat merupakan perwujudan nilai-nilai yang dianut oleh masyarakat, dijadikan patokan dalam bentuk tata cara, kebiasaan dan prilaku dalam berinteraksi sosial, keberadaannya bersifat mengikat bagi induvidu dan kelompok untuk dilaksanakan. Menurut Robert M.Z. Lawang Lawang (1985), nilai adalah gambaran mengenai apa yang diinginkan, sehingga pantas, dihargai dan dapat mepengaruhi perilaku sosial orang lain. Norma dan nilai dalam 
masyarakat dibentuk mulai keluarga, lingkungan budaya agama dan pendidikan. Masyarakat Pematang Gubernur memiliki keragaman suku, agama, budaya, pendidikan, dan tingkat kelas ekonomi, sehingga satu satunya ikatan sosial yang dipakai adalah norma yang dibentuk berdasarkan kesepakatan bersama.

Pembentukan norma dan nilai dilakukan melalui proses interaksi antar warga seperti interaksi antara anak-anak muda yang lebih intensif dalam bergaul. Situasi ini menjadikan norma dan nilai yang diidealkan masyarakat tanpa disadari terinternalisasikan masuk dalam diri individu dan akhirnya masuk ke dalam keluarga. Kebiasaan sehari-hari warga dijadikan patokan, perilaku yang baik bisa dijadikan contoh, budaya dijadikan panutan, dan ketentuan agama dijadikan pedoman sehingga tingkat gesekan yang berbau konflik dalam masyarakat sedikti demi sedikit menurun. Semuanya bisa terjadi karena masyarakat selalu ikut menjaga, memelihara dan mempertahan keberadaan nilai dan norma yang telah disepakati.

Pada kenyataannya, jika muncul persoalan atau masalah di tengah masyarakat, maka masyarakat cenderung menginginkan personalan diselesaikan secara kekeluargaan di tingkat desa. Masyarakat tidak ingin melaporkan ke aparat keamanan (kepolisian) karena ada anggapan di masyarakat bahwa persoalan tidak akan selesai dengan baik jika melibatkan kepolisian, tetapi malah justru yang terjadi akan muncul perasaan dendam antar yang berkonflik karena salah satu pihak harus membayar denda atau hukuman kurungan.

\section{Pemahaman tentang Kemiskinan}

Para sosiolog membedakan kemiskinan (poverty) menjadi dua: 1) Kemiskianan absolut adalah kemiskinan yang terjadi ketika orang tidak bisa mendapatkan kebutuhan untuk mendukung tingkat kesehatan fisik dan efisiensi minimum, yang sering diekspresikan dalam istilah tingkat ketercukupan kalori atau nutrisi. 2) Kemiskinan relatif adalah kemiskinan yang ditentukan oleh standar hidup umum dalam berbagai masyarakat dan apa yang secara kultural didefinisikan sebagai miskin daripada tingkat kemiskinan yang absolut. Ketika kemiskinan didefinisikan secara relatif, menurut standar kehidupan yang dinikmati sebagian besar populasi, tingkat kemiskinan akan berbeda di antara berbagai masyarakat dan di dalam masyarakat dari waktu ke waktu (Abercrombie et al. 2010: 433).

Keberadaan masyarakat Pematang Gubernur secara umumnya adalah para pendatang yang membeli rumah atau tanah, maka secara psikologis mereka sudah satu langkah ke depan dalam meniti kehidupannya, tinggal berjuang atau usaha untuk mendapatkan rezeki yang lebih banyak dibanding yang lainnya.

Hasilnya secara fisik dapat dilihat dari perkembangan bentuk rumah yang mengikuti perubahan jaman, serta dengan memiliki produk-produk industri dapat menjadi simbul status. Lain halnya dengan yang gagal dalam perjuangannya bisa dinyatakan tidak ada perubahan ke arah yang lebih baik. 
Secara sosiologis kegagalan dan keberhasilan yang dialami oleh setiap anggota masyarakat fungsional adanya, karena kehidupan masyarakat sesungguhnya saling tergantung satu sama lain dan menyatu dalam keseimbangan, sehingga setiap peran yang ada fungsional bagi masyarakat. Pada kenyataannya secara individu menjadi berbeda terutama bagi keluarga miskin, bahwa persoalan yang dihadapi bukan hanya sebatas memenuhi kebutuhan sehari-hari, tetapi masa depan anak jauh menjadi lebih penting, jika gagal dalam mengupayakan masa depan anak sama halnya mewariskan kemiskinan.

Ketidakmampuan seseorang dalam merubah nasib selalu diwarnai dengan berubahnya sikap dan prilaku hidup seharihari yang mengarah pada budaya miskin, sehingga masyarakat umum beranggapan bahwa masyarakat miskin adalah kelompok manusia malas yang tidak mau kerja keras.

\section{Ukuran Kemiskinan}

Sejalan dengan sifat kelompok sosial selalu mempunyai cara pandang yang sama dalam memahami pokok persoalan. Menurut George Caspar Homans dalam Herman Arisandi (2015), kelompok sosial merupakan sejumlah individu yang berkomunikasi satu dengan yang lain secara langsung dan jumlahnya tidak terlalu banyak, sedangkan komunitas adalah relasi pribadi yang erat dalam interest atau values.Masyarakat Pematang Gubernur memiliki sejarah yang hampir sama, sebagai keluarga baru yang datang dan bersama sama untuk meniti karir dan usaha, namun pada akhirnya memiliki nasib yang berbeda.
Bagi yang berhasil dianggap kaya dan yang gagal dianggap miskin, dan ukuran demikian sejalan dengan teori konflik Ralp Dahrendorf dalam George Ritzer (2009) bahwa masyarakat senantiasa berada dalam proses perubahan yang ditandai oleh pertentangan yang terus menerus diantara unsur-unsurnya. Pemahaman demikian menjadi berbeda kalau dihubungkan dengan konsep hidup bersama dalam bermasyarakat sebagaimana dikatakan Mack Ever dalam George Ritzer (2009) bahwa masyarakat sebagai suatu sistem dari cara kerja dan prosedur, otoritas dan saling bantu membantu.

Maka teori yang paling tepat untuk membedah realita sosial masyarakat Pematang Gubernur adalah teori struktur fungsional Robert K. Merton. Merton dalam George Ritzer (2009) menyebutkan bahwa masyarakat merupakan suatu sistem sosial yang terdiri atas bagian-bagian atau elemen yang saling berkait dan menyatu dalam keseimbangan. Sejalan dengan kondisi terbentuknya kelurahan yang diawali dari hadirnya para pendatang yang memiliki kesamaan ikatan suku dan agama menempati wilayah teritorial yang sama maka dapat dipamahi mereka merasa senasib sepenanggungan diperantauan.

Fase berikutnya adalah terbentunya ikatan budaya yang mengarah pada kesamaan pandang tentang nilai dan norma yang dijadikan ukuran dalam hidupnya. Hasil wawancara secara umum dapat disimpulkan sebaga berlkut: 1) Kelompok masyarakat Suku jawa yang menghuni Dusun Sidho Dadhi mengutamakan kualitas bangunan tempat tinggal 
dan berapa banyak bisa pulang ke daerah asal 2) Kelompok masyarakat Suku Batak yang menghuni wilayah dusun Medan Baru lebih mengutamakan berapa penghasilan yang bisa dikumpulkan. 3) Kelompok masyarakat Suku Serawai dusun Pematang gubernur ukurannya adalah luas kebon sawit yang dimiliki dan hasil yang diperoleh. 4) Kelompok masyarakat Suku Minang keberadaannya tersebar diseluruh dusun yang ada, ukurannya adalah perkembangan usaha yang dicapai dan berapa harta yang bisa dikumpulkan. 5) Warga perumahan UNIB ukurannya adalah tingkat pendidikan dan karir yang pernah dicapai. 6) Kelompok masyarakat Suku Lembak ukurannya berapa luas tahan yang pernah dikuasai dan berapa uang yang pernah dimiliki saat menjual tanah. 7) Warga perumahan umum yang berdiri di wilayah kelurahan Pematang Gubernur) masih belum nampak ukurnya karena rata-rata keluarga muda. 8) Satu lagi kelompok mapan yang datang membeli tanah dan rumah sekedar untuk investasi.

Sesuai dengan teori kelompok yang dikemukakan Ferdinand Tonnis dalam Kamanto Sunarto (2004) bahwa setiap induvidu yang tegabung dalam kelompok secara sosiologis dapat diketahui kesamaan sikap dan prilakunya terutama dalam mejaga memelihara dan memepertahan norma nilai yang disepakakti. Maka dengan mudah dapat dipetakan orientasi kelompok dalam memahami makna hidup dan kehidupannya.

Sejalan dengan ciri pembentukan sikap dalam kelompok,dapat rumuskan bahwa setiap induvidu akan hanyut dalam kelompok, demikian juga dalam membentukukuran orang kaya dan orang miskin lebih ditetapkan berdasarkan tetangga, karena dalam pandangan sosiologis manusia memiliki ruang batas interaksi yang membelenggu cara berfikir dalam hidupnya.

\section{Kajian Sosiologis}

Berdirinya Kecamatan Muara Bangkahulu dan Universitas Bengkulu tahun 1982 menjadi kutub pertumbuhan (growth pole) penduduk dan pembangunan fisik yang relatif lebih cepat dibanding daerah lain yang sama-sama berdiri. Kehadiran para pendatang secara fisik bisa dalam bentuk individu atau kelompok, namun pada dasarnya memiliki harapan yang hampir sama yaitu ingin ada perubahan yang lebih baik dibanding di daerah asal, dan hasil survey mendapat data tentang latar belakang pendatang sebagai berikut: 1) Program Pemerintah. 2) Mendekati tempat kerja. 3) Membeli tanah kaplingan. 4) Membeli perumahan. 5) Mengembangkan usaha, dan lain-lain.

Di tingkat kelurahan para pendatang yang menempati wilayah baru dihadapkan dengan masalah penyesuaian diri dengan sesama pendatang, antara lain karena latar belakang suku, budaya, agama dan perilaku yang berbeda, namun secara sosiologis menguntungkan. Adapun hasilnya sebagai berikut: 1) Mengetahui cara berinteraksi dengan induvidu atau kelompok. 2) Bisa hidup dalam kelompok dan tradisi yang berbeda. 3) Ikut membentuk norma dan nilai. 4) Ikut serta dalam memecahkan permasalahan sosial. 5) Mendapat kesadaran hidup saling membutuhkan. 6) Bisa mensyukuri hasil yang sekarang bisa dinikmati. 
Maka secara sosiologis peran yang harus dimainkan oleh setiap anggota masyarakat adalah taat pada aturan pemerintah, tunduk pada tata yang ada dan menjaga kesimbangan antar warga.

Kasus unik yang terjadi dalam wilayah penelitian adalah penduduk asli menjadi minoritas dan seluruh jabatan pemerintahan desa baik melalui pemilihan atau hasil penunjukan pemerintah semua dikuasai para pendatang. Demikian juga dengan praktik tata cara adat Suku Lembak tidak diberlakukan lagi karena di seluruh wilayah dusun Pematang Gubernur didominasi oleh pendatang. Bukti yang diperoleh di lapangan adalah bahwa setiap warga mendapat kebebasan menentukan cara ritual dan daur hidup sesuai dengan yang diinginkan atau berdasarkan latar belakang budaya, suku, dan agama yang dianut.

Hasil penelitian menunjukkan bahwa perbedaan yang terjadi dalam masyarakat Pematang Gubernur tidak menimbulkan konflik, justru membentuk budaya baru yang bernuansa kebhinnekaan. Maka secara sosiologis masyarakat Pematang Gubernur dapat dinyatakan secara fisik masuk wilayah administrasi Kota Bengkulu, tetapi secara kultural masih pedesaan. Ini dapat diamati dari beberapa kasus yang terjadi misalnya begitu ada warga yang kena musibah atau melaksanakan hajatan, maka seluruh warga bisa hadir dan tidak ada kantor pemerintahan atau swasta yang melarang karyawannya ijin pada jam kerja.

\section{Kesimpulan}

Penelitian tentang kemiskinan dalam perspektif sosiologi di Kelurahan Pematang Gubernur mendapat gambaran unik tentang pengembangan wilayah. Pada awalnya dimulai dengan hadirnya masyarakat Suku Jawa di dusun Sidho Dadhi melalui program transmigrasi lokal. Kemudian diikuti masyarakat Suku Serawai yang datang untuk berkebun, lalu Suku Batak membeli kaplingan tanah di dusun Baru dan akhirnya menjadi daerah hunian baru. Kemudian pada akhirnya di antara warga berusaha beradaptasi dengan lingkungan. Kesamaan sikap di antara warga melahirkan pandangan baru tentang ukuran kemiskinan yang ditetapkan berdasarkan keberhasilan dan kegagalan tetangga dalam meniti karir dan ekonomi.

Secara sosiologis keberadaan mereka terikat dalam bentuk kelompok kecil yang diatur oleh otoritas nilai-nilai kesukuan dan agama yang dianut. Akan tetapi dalam lingkup kelompok besar, mereka mendapati situasi yang sama yakini merasa senasib dan sepenanggungan sebagai sama-sama warga pendatang. Struktur sosial dan lembaga sosial masyarakat Kelurahan Pematang Gubernur masih mencari bentuk ideal, karena kondisi masyarakat sangat heterogen dan tempat tinggalnya yang berkelompok dalam bentuk perumahan dan perkampungan. Dengan kondisi ini, masyarakat tergoda untuk berpikiran sempit dalam memaknai arti kemiskinan. Masyarakat mengukur kemiskinan berdasarkan keberhasilan dan kegagalan dalam karir dan dalam usaha yang dicapai oleh tetangga. 
Saran

Berdasakan hasil penelitian menunjukkan bahwa ukuran kemiskinan masyarakat ditetapkan berdasarkan luas wilayah orientasi setiap anggota masyarakat. Salah satu buktinya adalah masyarakat selalu membandingkan keberhasilan atau kegagalan dirinya dengan tetangga, tidak pernah membandingkan dengan orang lain yang secara administrasi berjauhan wilayah. Berdasarkan hasil penelitian dapat kami sarankan sebagai berikut:Pertama, sebelum melakukan kebijakan dalam mengukur kemiskinan sebaiknya lakukan suvey kondisi sosial budaya masyarakat. Kedua, jangan sama ratakan ukuran kemiskinan setiap masyarakat. Ketiga, jangan sama ratakan cara membantu warga yang miskin.]

\section{Daftar Pustaka}

Abercrombie, Nicholas, Stephen Hill, dan Bryan S. Turner. 2010. Kamus Sosiologi. terj. Desi Noviyani. Yogyakarta: Pustaka Pelajar.

Adams, Charles. 1993. "Pertambahan Penduduk dan Penyerbuan Daerah Kota." dalam Kemiskinan di Perkotaan, terj. P. Suparlan. Jakarta: Yayasan Obor Indonesia.

Arisandi, Herman. 2015. Pemikiran Tokohtokoh Sosiologi, dari Klasik sampai Modern. Yogyakarta: IRCiSoD.

Bungin, Burhan. 2007. Metode Penelitian Kualitatif. Jakarta: Grafindo Persada.
Cahyadi, Rusli. 2011. "Kaum Miskin Kota, Sampah, dan Rumah: Studi tentang Akses Migran Miskin terhadap Sumber Daya Lingkungan dan Perumahan di Tangerang." Masyarakat: Jurnal Sosiologi 16(1):77-91. Retrieved (http://journal. ui.ac.id/index.php/mjs/article/viewArti cle/4875).

Cahyat, Ade. 2004. Bagaimana Kemiskinan Diukur. Bogor: Governance Brief.

Kleden, Ninuk dan Alie Humaedi. 2010. Kemiskinan dari Perspektif Kebudayaan. Jakarta: LIPI.

Lawang, Robert M. Z. 1985. Materi Pokok Sistem Sosial. Jakarta: Kurnika UT.

Moleong, J. Lexy. 2002. Metode Penelitian Kualitatif. Bandung: Remaja Rosdakarya.

Ritzer, George. 2009. Sosiologi Ilmu Pengetahuan Berparadigma Ganda. Jakarta: Rajawali Pers.

Soekanto, Soerjono. 2013. Sosiologi Suatu Pengantar. Jakarta: Rajawali Pers.

Sunarto, Kamanto. 2004. Pengantar Sosiologi. Jakarta: Universitas Indonesia Press.

Suparlan, Parsudi, ed. 1993. Kemiskinan di Perkotaan. Jakarta: Yayasan Pustaka Obor Indonesia.

Suyanto, Bagong. 1995. Perangkap Kemiskinan: Problem \& Strategi Pengentasannya. terj. B. Suyanto. Surabaya: Universitas Airlangga Press.

Syawie, Mochamad. 2011. "Kemiskinan dan Kesenjangan Sosial." Media Informasi Penelitian Kesejahteraan Sosial 16(3). 